\title{
Production of alkaline pectinase: a case study investigating the use of tobacco stalk with the newly isolated strain Bacillus tequilensis CAS-MEI-2-33
}

Ge Zhang ${ }^{1,2,3}$, Shugui Li', Yingbo Xu ${ }^{5}$, Juan Wang ${ }^{3}$, Fan Wang ${ }^{2}$, Yuhua Xin ${ }^{3}$, Zhong Shen ${ }^{3}$, Haibo Zhang ${ }^{2}$, Ming $\mathrm{Ma}^{4^{*}}$ and Haobao Liu ${ }^{1,3^{*}}$

\begin{abstract}
Background: Tobacco stalk (TS), a major agricultural waste abundant in pectin, has resulted in concerns about the need for its reuse. The nicotine in TS is considered a chemical that is tolxic and hazardous to the environment.

Results: In this study, Bacillus tequilensis CAS-MEI-2-33 was isolated from cigar wrappers to produce alkaline pectinase using TS. Subsequently, the medium and fermentation conditions for the production of pectinase by $B$. tequilensis CAS-MEI-2-33 were optimized. The optimal fermentation period, $\mathrm{pH}$ of the initial fermentation medium, concentration of TS, and inoculum amount for B. tequilensis CAS-MEl-2-33 were $40 \mathrm{~h}, 40 \mathrm{~g} / \mathrm{L}, 7.0$, and 3\%, respectively. Under optimal conditions, the pectinase activity was $1370 \mathrm{U} / \mathrm{mL}$. Then, the enzymatic properties, such as the optimum $\mathrm{pH}$, reaction temperature, temperature stability, and effects of metal ions, were studied. The optimal pH was determined to be 10.0, indicating that the enzyme was an alkaline pectinase. The optimal temperature was $40^{\circ} \mathrm{C}$, and pectinase activity was stable at $40^{\circ} \mathrm{C}$. The $\mathrm{Ag}^{+}$metal ions were shown to remarkably promote enzyme activity. The pectinase was partly purified by ammonium sulfate precipitation, ion exchange chromatography, and Sephacryl S-100 chromatography. Sodium dodecyl sulfate-polyacrylamide gel electrophoresis (SDS-PAGE) and LC-MS/MS analyses were utilized to analyze the pectinase.
\end{abstract}

Conclusions: This study provided a new alkaline pectinase candidate and a new strategy for the use of TS.

Keywords: Alkaline pectinase, Tobacco stalk, Screening Bacillus tequilensis, Fermentation, Enzymatic properties, Purification

\section{Background}

Extremely large quantities of agro-industrial waste residues are generated from the processing of raw materials, such as tobacco stalk (TS), which is an abundant crop residue in China. It has been estimated that more than one hundred thousand metric tons of TS are discarded annually in China ([1] \#1136). Stricter environmental

\footnotetext{
*Correspondence: 228532536@qq.com; liuhaobao@caas.cn; 188702236@163.com

${ }^{4}$ China Tobacco Standardization Research Center, Zhengzhou Tobacco Research Institute of CNTC, Zhengzhou 450001, People's Republic of China ${ }^{1}$ Key Laboratory of Tobacco Biology and Processing, Tobacco Research Institute of Chinese Academy of Agricultural Sciences, Qingdao 266101, People's Republic of China

Full list of author information is available at the end of the article
}

legislation for tobacco industries in China has forced these industries to seek an environmentally friendly process for the disposal of tobacco waste. The use of TS would not only decrease the soil pollution caused by its improper disposal but also provide additional income for the tobacco producers ([2] \#1155). Some progress has been made in the use of TS, such as the extraction of chemicals ([3] \#1227), reconstituted tobacco or filler ([4] \#1051), and nanofibrillated cellulose ([5] \#1210). However, new approaches are necessary for the safe and sustainable use of TS.

Pectinase is widely used in food ([6] \#1172), paper, pulp ([7] \#1095), and textile industries ([8] \#918). This enzyme can be used for the degradation of pectin 
substances in plant tissues. Several microorganisms, including bacteria and fungi, have been shown to produce pectinase ([9] \#1173). To reduce production costs, agro-waste sources, such as fruit waste ([10] \#1101; [11] \#1092), carrot waste ([12] \#1098), and onion wastes ([13] \#1211), have been used to produce pectinase using microbial solid-state fermentation. Furthermore, bacterial pectinase is preferred over fungal pectinase because of the ease of fermentation and modern techniques for improving production yield ([11] \#1092). In addition, pectinases can be classified into acidic and alkaline enzymes according to the optimal $\mathrm{pH}$ for enzymatic activity. Alkaline enzymes, which are almost exclusively produced by bacteria, have numerous applications, such as textile processing; pharmaceutical uses; and leather, detergent and paper production ([6] \#1172; [14] \#1304).

Based on these criteria, we screened bacteria that could produce pectinase using TS, which is abundant in pectin (approximately 10\%) ([15] \#1141). Furthermore, the morphological and molecular characteristics of the isolated strain were analyzed. The enzyme properties, production processes with TS, and the purification of the pectinase were studied. This study provides a new strategy for the use of TS and helps lay the foundation for the production of pectinase.

\section{Results}

\section{Screening of isolates for pectinase activity}

Pectinase has many applications in various industrial processes ([16] \#1170; [17] \#1311). To screen excellent strains for pectinase production, some isolates from the primary screening were spot inoculated on pectin agar plates (PAPs) in triplicate. An additional image was shown this in more detail [see Additional file 1: Figure S1]/(see Additional file 1). The Hc value of 33 for this isolate was significantly higher than the values for other isolates $(8.87 \pm 0.15$, Fig. 1$)$. This bacterium was labeled as isolate $B$. tequilensis CAS-MEI-2-33, and further characterization and identification were carried out.

\section{Morphological characteristics of $B$. tequilensis CAS-MEI-2-33}

$B$. tequilensis CAS-MEI-2-33 was a gram-positive bacterium that contained spores, and the shape of the bacterial cells was clubbed. When grown at $37^{\circ} \mathrm{C}$ for $8-$ $12 \mathrm{~h}$ in LB agar, colonies of B. tequilensis CAS-MEI-2-33 were round, smooth, and cream colored, and the margin was entire.

Biochemical characterization of $B$. tequilensis CAS-MEI-2-33 The biochemical characterization of $B$. tequilensis CASMEI-2-33 was performed using a variety of tests, including the Voges-Proskauer, nitrate reduction, glucose utilization, catalase, motility, lysozyme tolerance, phenylalanine, gelatin, starch, lactose, casein, and mannitol tests. The results of the phenylalanine, starch, and mannitol tests were negative, while the results of the remaining tests were positive (Table 1).

\section{Identification based on phylogenetic analysis}

The phylogenetic tree generated using the 16S rRNA gene sequence of the bacterial isolate showed the highest homology (100\%) with B. tequilensis. Furthermore, the biochemical characterization of the ability of CASMEI-2-33 to metabolize starch and mannitol was different from that of Bacillus subtilis but similar to that of $B$. tequilensis. According to Bergey's Manual of Determinative Bacteriology, this strain was named $B$. tequilensis CAS-MEI-2-33 ([18] \#1309). The constructed phylogenetic tree indicated that this strain had the closest genetic relationship with the B. tequilensis strain $\mathrm{P} 12 \mathrm{~Pb}$ (Fig. 2). The tree was inferred by the neighbor-joining method using MEGA 7.0 software. The numbers at the nodes of the tree are indications of the levels of bootstrap support based on neighbor-joining analysis of 1000 inferred replications.

\section{Toxicity of nicotine to $B$. tequilensis CAS-MEI-2-33}

TS, contains nicotine, which is harmful to many bacteria, and serves as a distinct source of nutrition. The average nicotine content in TS is as high as 1900-3800 $\mathrm{mg} / \mathrm{kg}$ ([1] \#1136), which is equal to $76-152 \mathrm{mg} / \mathrm{L}$ in the fermentation medium. In this study, $500-2000 \mathrm{mg} / \mathrm{L}$ nicotine in the medium was tested. The highest concentration of nicotine in the test medium was approximately 13 times that in the TS fermentation medium. However, the growth of B. tequilensis CAS-MEI-2-33 was less affected under the experimental conditions (Fig. 3).

\section{Production of pectinase}

The production of high titers of pectinase by optimizing the growth parameters is of prime importance in industry ([19] \#1145). In the present study, the one-factor-at-a-time method was implemented to optimize the components of the medium and conditions. The enzymatic activity was detected using 3,5-dinitrosalicylic acid (DNS) reagent (Beijing Leagene Biotech. Co., Ltd.) based on the production of D-galacturonic acid ([20] \#1161). The curve for the production of pectinase during the fermentation of $B$. tequilensis CAS-MEI-2-33 was pivotal for indicating the optimal fermentation. The activity of pectinase increased gradually until $40 \mathrm{~h}$, except for $32 \mathrm{~h}$, and then began to decline (Fig. $4 \mathrm{a}$ ). The highest pectinase activity for the process of fermentation using TS as the feedstock was $293 \mathrm{U} / \mathrm{mL}$ at $40 \mathrm{~h}$. Parameters such as the $\mathrm{pH}$ of the fermentation medium have a substantial influence on the growth of strains and pectinase production. Pectinase activity $(618 \pm 9$ 


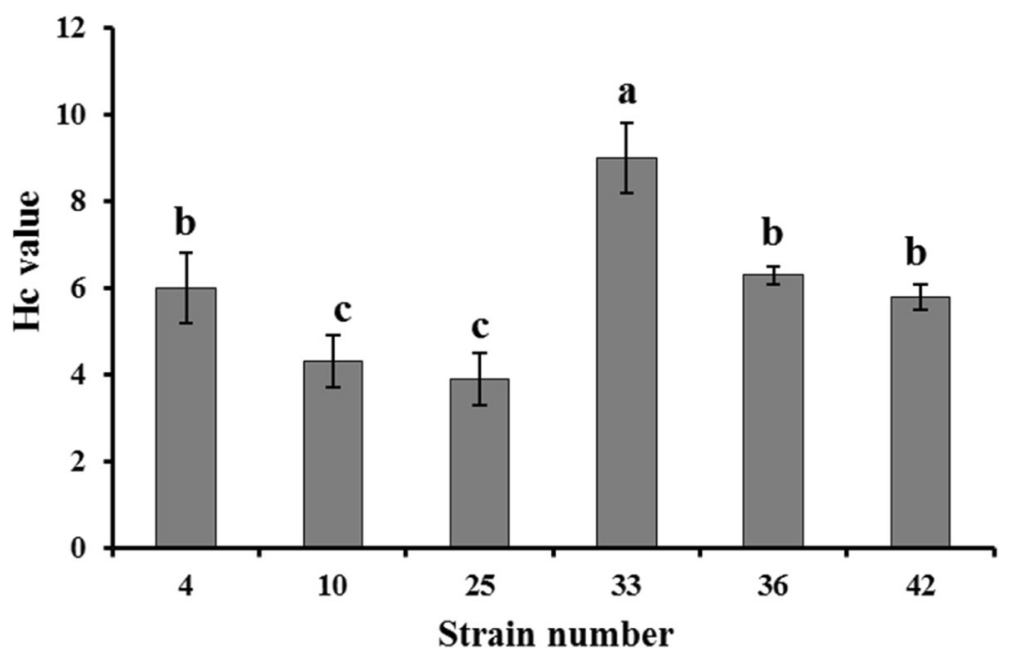

Fig. 1 The Hc values of screened strains. Values are given as the means \pm standard deviation $(n=3)$. Different letters indicate significant differences at $5 \%$

$\mathrm{U} / \mathrm{mL}$, Fig. $4 \mathrm{~b})$ was significantly increased at $\mathrm{pH} 7.0$ compared to that under other conditions.

After the determination of pectinase activity with different concentrations of TS in the fermentation medium, it was found that at the concentration of $40 \mathrm{~g} / \mathrm{L}$ TS and the optimized $\mathrm{pH}$, pectinase activity was the highest $(730 \pm 38 \mathrm{U} / \mathrm{mL}$, Fig. $4 \mathrm{c})$, as supported by ANOVA ( $p=$ $0.05)$.

The inoculum amount played a key role in the initial fermentation. Under the optimal $\mathrm{pH}$ and TS concentration, inoculum concentrations of $1,3,5,7$, and $9 \%$ were tested. The highest pectinase activity $(1370 \pm 126 \mathrm{U} / \mathrm{mL}$, Fig. $4 \mathrm{~d})$ with $3 \%$ inoculum was not significantly different from that with 5\% inoculum. At higher levels, such as 7 and $9 \%$, enzyme production declined, which could be due to competition for nutrients among the population of bacteria, as

Table 1 Biochemical characterization of the isolate $B$. tequilensis CAS-MEI-2-33. (+, positive; -, negative)

\begin{tabular}{ll}
\hline Biochemical test & CAS-MEI-2-33 \\
\hline Voges-Proskauer & + \\
Nitrate reduction & + \\
Glucose utilization & + \\
Catalase & + \\
Motility & + \\
Lysozyme tolerance & + \\
Phenylalanine & - \\
Gelatin & + \\
Starch & - \\
Lactose & + \\
Casein & + \\
Mannitol & - \\
\hline
\end{tabular}

has been observed in Thermomucor indicae-seudaticae ([21] \#1230).

\section{Pectinase properties}

The results of the pectinase property analysis are shown in Fig. 5. The $\mathrm{pH}$ of the reaction system can affect pectinase activity. Pectinase activity increased when the $\mathrm{pH}$ of the reaction systems was increased from 6.0 to 10.0, but this activity was nearly undetectable at $\mathrm{pH} 11.0$. Our results showed that $791 \pm 42 \mathrm{U} / \mathrm{mL}$ pectinase activity at pH 10.0 was the highest recorded value (Fig. 5a). Subsequently, the influence of temperature on pectinase activity was investigated. Pectinase activity increased when the reaction temperature was increased from $30^{\circ} \mathrm{C}$ to $40{ }^{\circ} \mathrm{C}$, reached maximum activity at $40^{\circ} \mathrm{C}$, and then decreased rapidly as the temperature increased beyond $40{ }^{\circ} \mathrm{C}$. The pectinase activity at $40{ }^{\circ} \mathrm{C}$ was higher than that at other temperatures (Fig. $5 \mathrm{~b}$ ). Thus, pectinase was more active at an alkaline $\mathrm{pH}$ and intermediate temperature. The effects of different metal ions on pectinase activity are shown in Fig. 5 c. $\mathrm{Ag}^{+}, \mathrm{Li}^{+}, \mathrm{Cu}^{2+}, \mathrm{Ca}^{2+}$, $\mathrm{Ba}^{2+}$, and $\mathrm{Mn}^{2+}$ ions increased enzyme activity; in particular, $\mathrm{Ag}^{+}$ions increased pectinase activity by $193.95 \%$, which was approximately 1.94 times higher than that of the control. $\mathrm{K}^{+}, \mathrm{Co}^{2+}, \mathrm{Ni}^{2+}, \mathrm{Mg}^{2+}, \mathrm{Zn}^{2+}, \mathrm{Cd}^{2+}$, and $\mathrm{Fe}^{3+}$

Table $\mathbf{2}$ The partial purification results of alkaline pectinase

\begin{tabular}{lllll}
\hline & $\begin{array}{l}\text { Total } \\
\text { activity }(U)\end{array}$ & $\begin{array}{l}\text { Total } \\
\text { protein (ug) }\end{array}$ & $\begin{array}{l}\text { Specific } \\
\text { activity }\end{array}$ & $\begin{array}{l}\text { Purification } \\
\text { fold }\end{array}$ \\
\hline Fermentation liquid & $4,074,513$ & $7,859,964$ & 0.5 & 1 \\
Ammonium sulfate & 284,144 & 166,842 & 1.7 & 3.3 \\
High-Q-8.0 & 77,611 & 15,066 & 5.2 & 10.2 \\
Sephacryl S-100 & 41,357 & 1580 & 26.2 & 51.4 \\
\hline
\end{tabular}




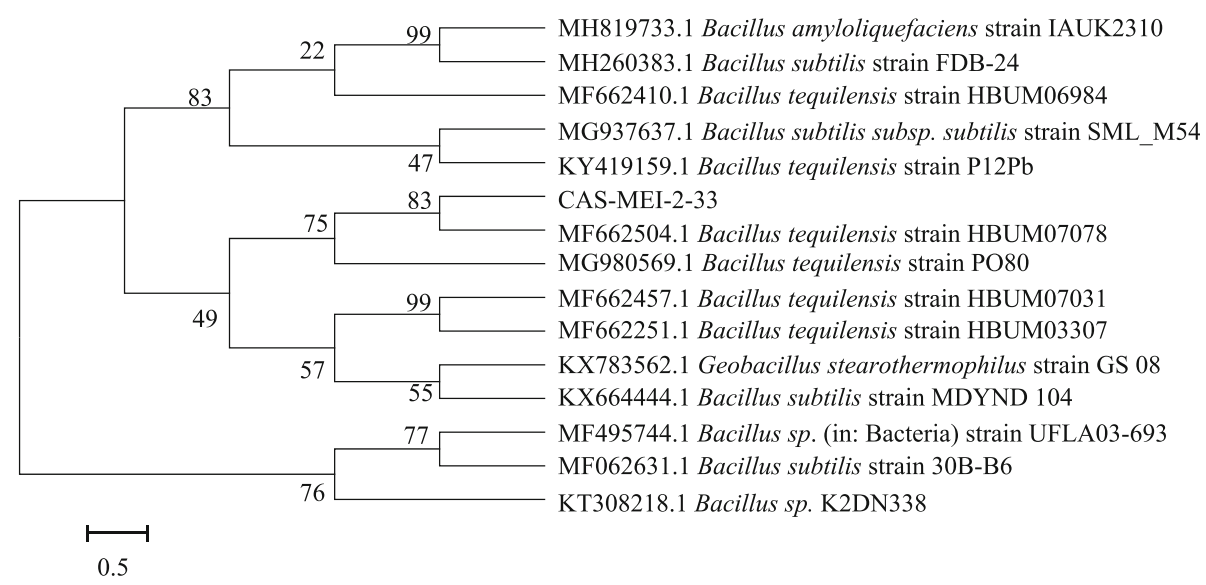

Fig. 2 Phylogenetic tree based on 165 ribosomal RNA sequence analysis showing the position of the strain CAS-MEI-2-33 using MEGA 7.0 software. Numbers at branching points refer to bootstrap values (1000 resamplings) with 0.50 as the sequence divergence

ions, especially $\mathrm{Zn}^{2+}$, inhibited pectinase activity. Figure $5 \mathrm{~d}$ shows the thermal stability of pectinase produced by $B$. tequilensis CAS-MEI-2-33. However, pectinase activity decreased when the cell-free supernatant was placed at $60^{\circ} \mathrm{C}$. Pectinase activity was stable when the cell-free supernatant was incubated at $40^{\circ} \mathrm{C}$; however, pectinase could not tolerate the high temperature for a long time.

\section{Partial purification of pectinase from CAS-MEI-2-33}

Under the optimal fermentation conditions, $2.30 \mathrm{~L}$ supernatant was obtained by centrifuging the bacteria in a $3.0 \mathrm{~L}$ fermentation flask. The pectinase activity reached $1771 \mathrm{U} / \mathrm{mL}$, and the total pectinase activity was 4,074,513 U (Table 2).

According to the ammonium sulfate fractionation curve, suitable saturation was selected for salting out. The fractionation curve is shown in Fig. 6a. When ammonium sulfate was saturated to $70-80 \%$, the pectinase activity of the precipitate increased, while that of the supernatant decreased significantly. When the saturation rate reached $80-90 \%$, the pectinase activities $(\mathrm{pH}$ 10.0, Gly-NaOH) of the precipitate and supernatant did not change significantly. The target protein was

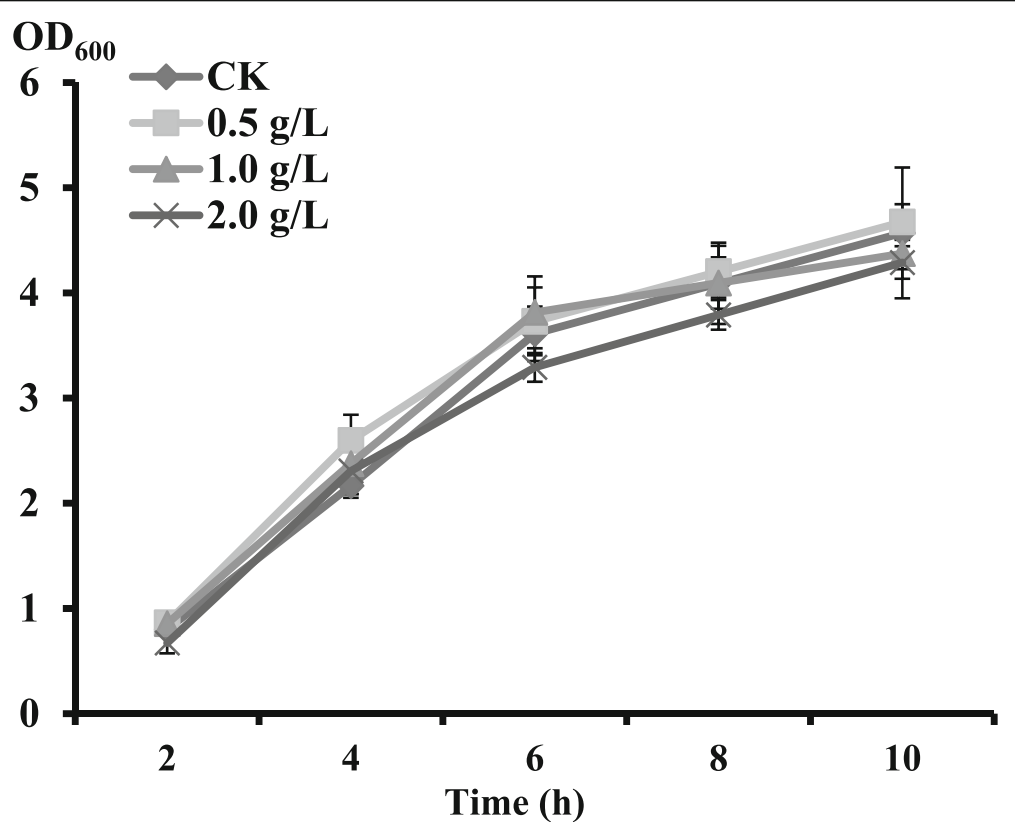

Fig. 3 The growth of B. tequilensis CAS-MEI-2-33 under different concentrations of exogenous nicotine. Values are given as the means \pm standard deviation $(n=3)$ 


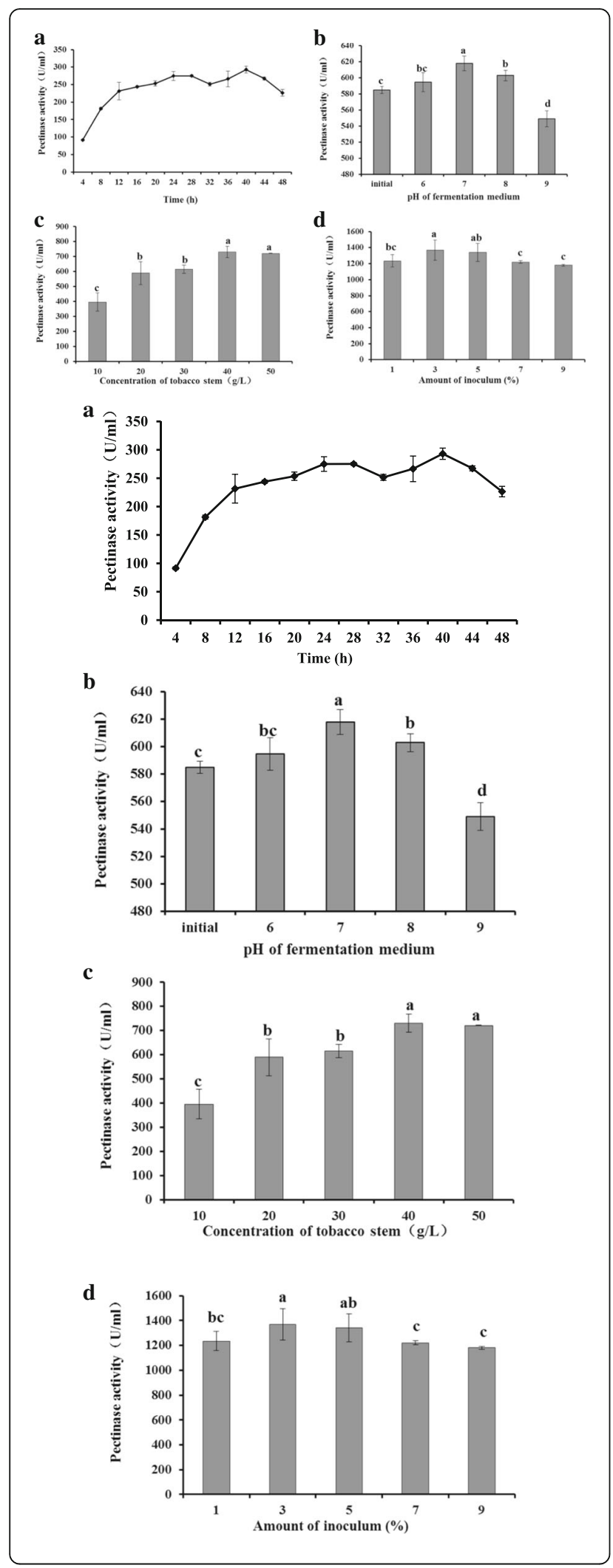

Fig. 4 Pectinase activity of $B$. tequilensis CAS-MEI-2-33 during fermentation. a Pectinase activity during $B$. tequilensis CAS-MEI-2-33 growth. $\mathbf{b}$ Effect of the initial $\mathrm{pH}$ of fermentation medium on enzyme activity. c Effect of tobacco stalk concentration in the fermentation medium on enzyme activity. $\mathbf{d}$ Effect of the amount of inoculum on enzyme activity. Values are given as the means \pm standard deviation $(n=3)$. Different letters indicate significant differences at $5 \%$

dissolved with $30 \mathrm{~mL}$ buffer $(\mathrm{pH}$ 8.0, Tris- $\mathrm{HCl}$ ) after salting out. Then, the target protein was further renatured with $55.0 \mathrm{~mL}$ buffer ( $\mathrm{pH} 8.0$, Tris- $\mathrm{HCl}$ ) through a dialysis bag. The pectinase activity was $5166 \mathrm{U} / \mathrm{mL}$, and the total activity was 284,144 $\mathrm{U}$.

After dialysis, the supernatant was purified with a Mini Macro-Prep High-Q ion exchange column. The results are shown in Fig. 6b. The pectinase was eluted with $\mathrm{pH}$ 8.0 Tris- $\mathrm{HCl}$ buffer, and when the column was gradiently eluted with $\mathrm{pH} 8.0$ Tris- $\mathrm{HCl}$ buffer containing $0-1$ $\mathrm{mol} / \mathrm{L} \mathrm{NaCl}$, peaks eluted. By detecting pectinase activity, it was found that the first elution peak was active. The first elution peak was collected with pectinase activity of $862,352 \mathrm{U} / \mathrm{mL}$. The total activity was $77,611 \mathrm{U}$. Sephacryl S-100 was equilibrated with ultrapure water, sampled, and then eluted with $\mathrm{pH} 7.2 \mathrm{PBS}$ buffer, with a flow rate of $0.8 \mathrm{~mL} / \mathrm{min}$, and the effluent was detected online by a UV detector at a wavelength of $280 \mathrm{~nm}$ to record the ultraviolet absorption peak curve (Fig. 6c). The components were collected and used for the determination of enzyme activity and protein content. The pectinase activity was $13,786 \mathrm{U} / \mathrm{mL}$, and the total activity was $41,357 \mathrm{U}$.

The molecular weight of the purified alkaline pectinase was detected with SDS-polyacrylamide gel electrophoresis (PAGE) as described by Mehrnoush et al. ([22] \#1306). The molecular weight of the pectinase, which was approximately $45.4 \mathrm{kDa}$, is shown in Fig. $6 \mathrm{~d}$. Then, the protein band was cut from the SDS-PAGE gel, subjected to LC-MS/MS analysis by Shanghai Applied Protein Technology ([23] \#1320; [24] \#1321), and identified by searching the UniProt database. The additional figure about protein base peak was shown this in more detail [see Additional file 2: Figure S2]/(see Additional file 2 for protein peak). Finally, the protein was identified as pectate lyase, the sequence was K.ASSSNVYTVSNR.N (Fig. 7). The molecular weight was $45.4 \mathrm{kDa}$, which was consistent with the SDS-PAGE results. The results indicated that the enzyme was a good candidate for pectate lyase. Furthermore, this study was a new attempt to recycle and reuse TS in agricultural production.

\section{Discussion}

This study made a successful primary attempt to produce pectinase using TS with a new strain. In previous studies, a variety of microorganisms were identified as 

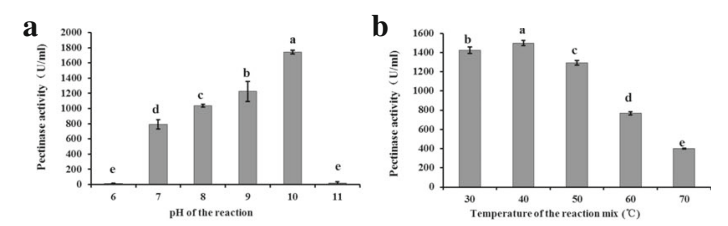

c
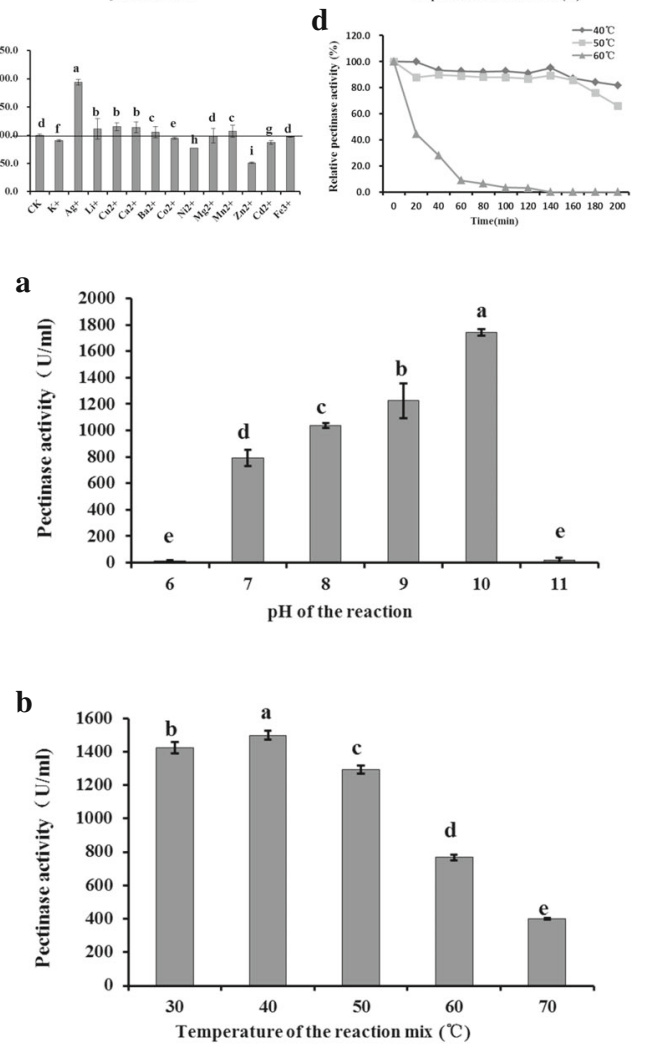

c
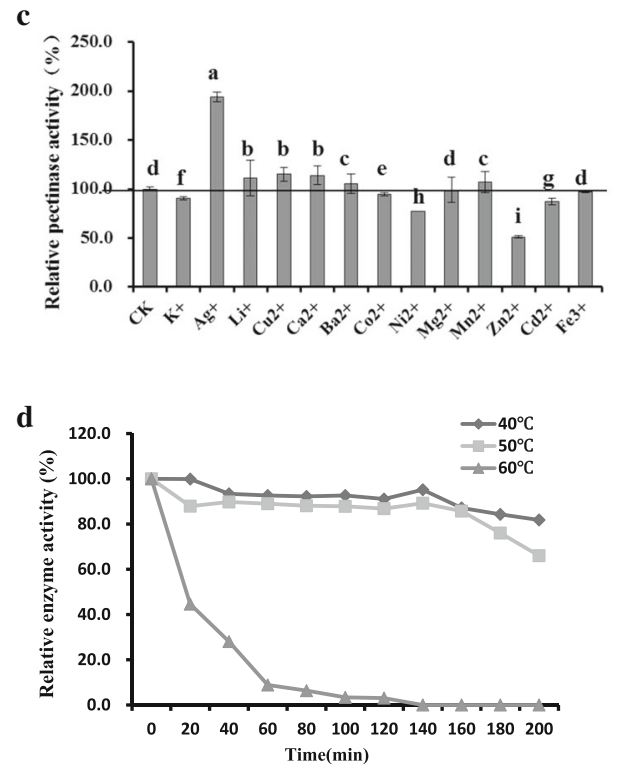

Fig. 5 Enzymatic properties of pectinase. a Effect of substrate $\mathrm{pH}$ on pectinase activity. $\mathbf{b}$ Effect of reaction temperature on pectinase activity. c Effect of metal ions on pectinase activity. $\mathbf{d}$ Temperature stability of pectinase. Values are given as the means \pm standard deviation $(n=3)$. Different letters indicate significant differences at $5 \%$

pectinase producing, including B. subtilis ([8] \#918; [25] \#921), B. megaterium ([26] \#1152), Rhizopus oryzae ([27] \#1147), Aspergillus oryzae ([10] \#1101), and B. tequilensis ([28] \#1307).

In addition, it was critical to determine the fermentation period of $B$. tequilensis CAS-MEI-2-33 during optimization experiments. The one-factor-at-a-time method was implemented to optimize the components of the medium and conditions, especial the $\mathrm{pH}$ of medium. The optimum $\mathrm{pH}$ for the growth of and pectinase production by other bacterial strains, such as $B$. subtilis ([8] \#918), has been recorded to vary from 7.0 to 10.0. Meneghel et al. ([29] \#1193) and Fawole and Odunfa ([30] \#1231) have reported that pectinase production by Aspergillus fungi occurs at an acidic $\mathrm{pH}$. Different strains have species-specific acid-base conditions for their growth and fermentation processes. And then, as the primary carbon source in the medium, the concentration of TS exerted a profound effect on pectinase production by $B$. tequilensis CAS-MEI-2-33. However, pectinase activity with $50 \mathrm{~g} / \mathrm{L}$ TS in the fermentation medium was not significantly different from that with $40 \mathrm{~g} / \mathrm{L} \mathrm{TS}$, and this similarity might be caused by the other components, such as tobacco-specific nitrosamines (TSNAs) ([31] \#1310).In the optimized fermentation (40 h, pH 7.0, $40 \mathrm{~g} / \mathrm{L} \mathrm{TS}, 3 \%$ inoculum), the highest pectinase activity was $1370 \mathrm{U} / \mathrm{ml}$. By optimizing the inoculum amount, pectinase activity was improved 1.88 times. The results indicated that the $B$. tequilensis CAS-MEI-2-33 strain was a good candidate for biorefining TS. In subsequent experiments, optimization to improve the efficiency of pectinase production using TS and exploration of applications in industry, as conducted by Swarupa Rani Chiliveri ([28] \#1307), would attract more interest.

The properties of pectinase are important in the application of this enzyme ([16] \#1170); in particular, enzyme deactivation and stability are considered major constraints. The pectinase enzymes from different strains exhibited different properties ([16] \#1170). In this study, the enzyme was an alkaline pectinase, which has various environmental and economic applications, such as textile processing; pharmaceutical uses; and leather, detergent and paper industry ([6] \#1172). Pectinase is produced by both prokaryotic microorganisms, which almost exclusively synthesize alkaline pectinases, and eukaryotic microorganisms, which synthesize acid pectinases ([6] \#1172). Ping \& Chaochao reported that the 

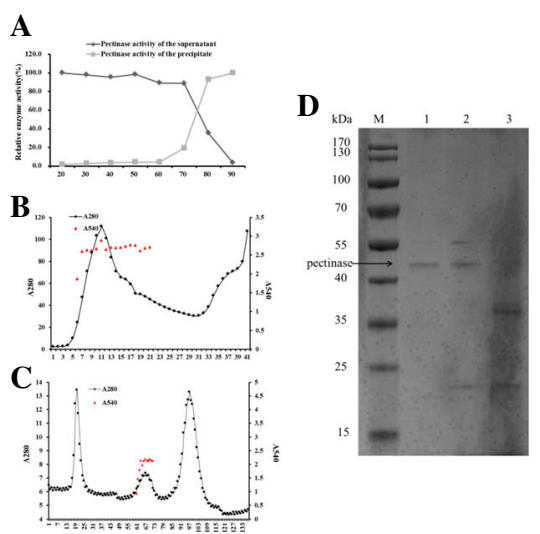

A

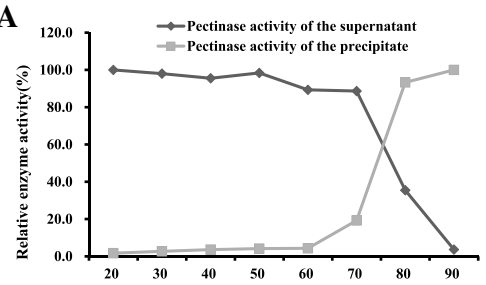

B

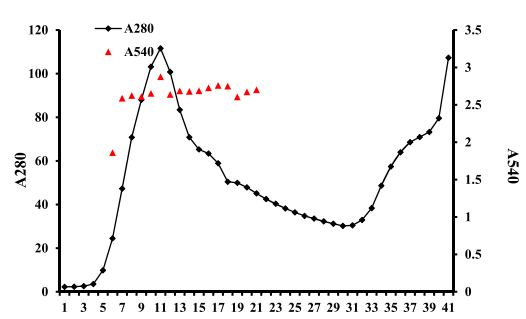

C

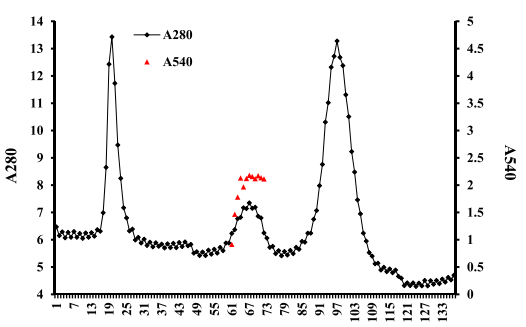

D

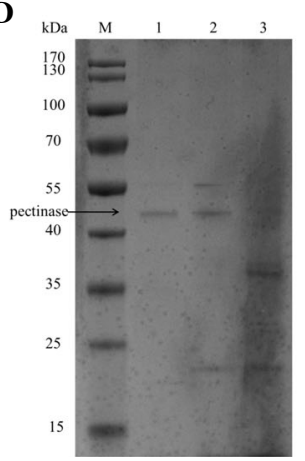

Fig. 6 The purification of alkaline pectinase from B. tequilensis CASMEI-2-33. a Ammonium sulfate fractionation curve; b Elution curve of Mini Macro-Prep High-Q ion exchange chromatography; c. Elution curve of Sephacryl S-100 column chromatography; $\mathbf{d}$. The partial purification of alkaline pectinase from $B$. tequilensis CAS-MEI-2-33 using TS. M: molecular weight makers; 1. Sephacryl S-100 column chromatography with $\mathrm{pH}$ 7.2; 2: Mini Macro-Prep High-Q ion exchange chromatography with pH 8.0; 3. Concentrated ammonium sulfate salting out solution

optimal $\mathrm{pH}$ for pectinase production by Bacillus sp. was 5.0 ([32] \#1221). The difference in optimal pH might be caused by the strain or fermentation medium. This is the first report of the ability of $B$. tequilensis strain to produce pectinase using TS and provides a direction for further investigation of the possible applications of TS.

\section{Conclusions}

This study successfully determined that the strain isolated from the cigar wrapper was a potential candidate organism that was useful in the production of pectinase using TS. The B. tequilensis CAS-MEI-2-33 strain will not only aid in addressing TS waste but also increase the possible sources of alkaline pectinase. The medium and culture conditions for this strain were optimized in this study. Based on the optimized conditions ( $\mathrm{pH}$ 7.0, $40 \mathrm{~g} / \mathrm{L}$ TS, $3 \%$ inoculation, and $40 \mathrm{~h}$ cultivation), the highest enzymatic activity of the strain was $1370 \mathrm{U} / \mathrm{mL}$. The enzymatic properties were studied, including the $\mathrm{pH}$ of the reaction buffer, reaction temperature, effects of metal ions, and thermal stability. The alkaline pectinase was relatively stable at $40{ }^{\circ} \mathrm{C}$, and the molecular weight was approximately $45.4 \mathrm{kDa}$. This is the first report of the ability of the $B$. tequilensis strain to produce pectinase using TS and provides a direction for further investigation of the possible applications of TS.

\section{Methods}

\section{Primary screening}

Samples collected from the cigar wrapper leaf from the Haikou Cigar Research Institute, Hainan Provincial Branch of the China National Tobacco Corporation, were diluted with $0.9 \%$ sterile $\mathrm{NaCl}$ solution and then plated onto pectin agar plates (PAPs) containing 0.5\% pectin (galacturonic acid $\geq \geq 74.0 \%$, Shanghai Macklin Biochemical Co., Ltd.), 0.1\% $\mathrm{K}_{2} \mathrm{HPO}_{4}, 0.3 \%\left(\mathrm{NH}_{4}\right)_{2} \mathrm{SO}_{4}$, $0.001 \% \mathrm{Fe}_{2} \mathrm{SO}_{4}, 0.1 \% \mathrm{MgSO}_{4}$, and $1.8 \%$ agar powder. Inoculated plates were incubated for $48 \mathrm{~h}$ at $37^{\circ} \mathrm{C}$ to obtain bacterial colonies. Colonies were picked, inoculated on fresh PAPs, and incubated at $37^{\circ} \mathrm{C}$ for $48 \mathrm{~h}$ to obtain pure cultures. The pure cultures were maintained on Luria-Bertani (LB) agar plates at $4{ }^{\circ} \mathrm{C}$ and stored at $80^{\circ} \mathrm{C}$ with $15 \%$ glycerol for further use. 


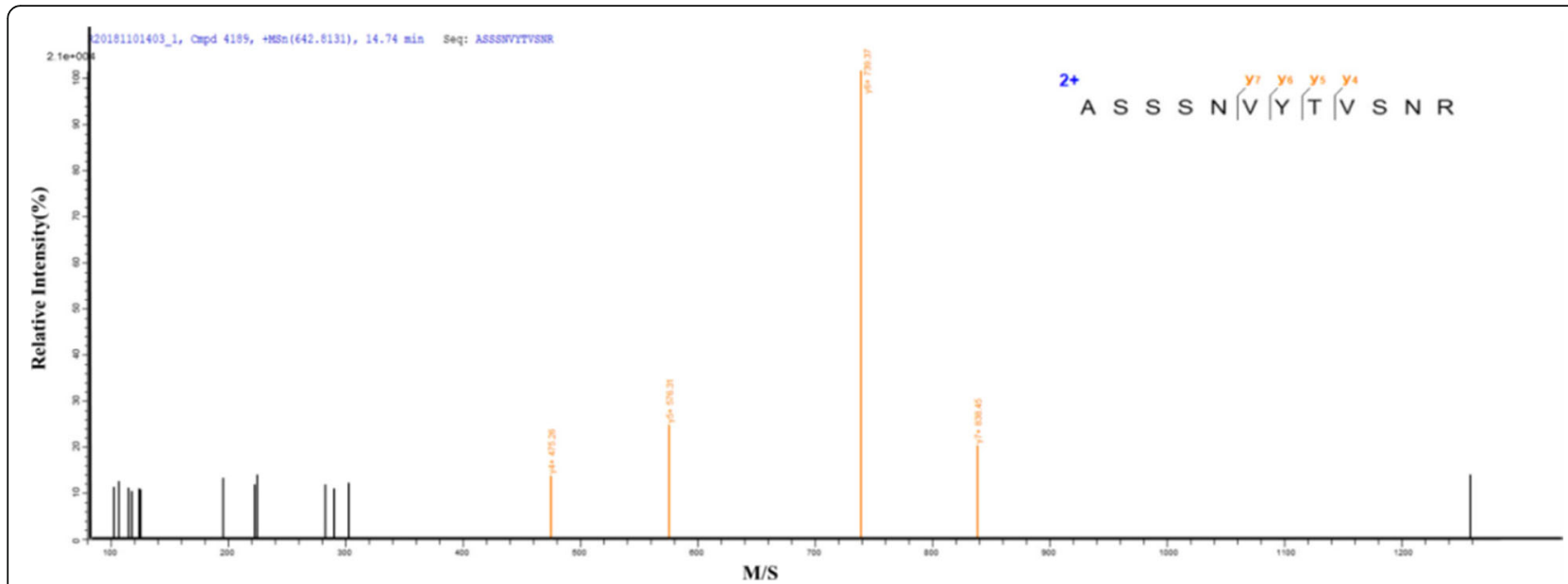

Fig. 7 LC-MS/MS analysis of protein bands by SDS-PAGE

\section{Secondary screening}

The bacterial isolates from the primary screening were tested for their ability to produce pectinases. The isolates were spot inoculated on PAPs in triplicate and incubated at $37^{\circ} \mathrm{C}$ for $36-48 \mathrm{~h}$. Depending on the zone of clearance surrounding the colonies (Hc value, the ratio of the diameter between clearance and the strain) using Congo red (Shanghai Aladdin Bio-Chem Technology Co., Ltd.) ([10] \#1101), the strain used for further experiments was selected.

\section{Identification of the isolated bacterial strain}

The isolated bacterial strain was identified according to morphological, physiological, and biochemical characteristics, as well as phylogenetic analysis of the $16 \mathrm{~S}$ ribosomal RNA (rRNA) gene. Morphological characteristics of the isolated bacterial strain, e.g., colony morphology (color, shape, margin, and surface) and cell morphology (shape and Gram staining), were studied ([25] \#921). The biochemical characteristics of the strain were studied with microbial biochemical identification tubes (Guangdong Huankai Microbial Sci. \& Tech. Co., Ltd.). These biochemical and characterization tests include the Voges-Proskauer, nitrate reduction, glucose utilization, catalase, motility, lysozyme tolerance, phenylalanine, gelatin, starch, lactose, casein, and mannitol tests. The $16 \mathrm{~S}$ rRNA gene fragment of the strain was obtained using polymerase chain reaction (PCR) amplification with universal primers (BGI Life Tech Co., Ltd., Qingdao, China): 27F $\left(5^{\prime}-3^{\prime}\right)$ : AGAGTTTGATCCTGGCTCAG and 1492R (5'-3'): ACGGCTACCTTGTTACGACTT. The reaction mixture was prepared in a final reaction volume of $50 \mu \mathrm{l}$ consisting of $25.0 \mu \mathrm{l}$ Premix Taq ${ }^{\text {Tix }}$ (LA Taq $^{\text {Ta }}$ Version 2.0, Takara Bio, Japan), $1.0 \mu \mathrm{l} 10 \mu \mathrm{M}$ primers, $1.0 \mu \mathrm{l}$ genomic DNA template $(57 \mathrm{ng} / \mu \mathrm{l})$, and $22.0 \mu \mathrm{ldd} \mathrm{d}_{2} \mathrm{O}$. The genomic DNA of $B$. tequilensis
CAS-MEI-2-33 was extracted with a TIANamp Bacteria DNA Kit (TIANGEN Biotech, Beijing) according to the manufacturer's instructions. The PCR products were detected using $1.0 \%$ agarose gel electrophoresis. The product of the appropriate size (1.5 kbp) was sequenced (BGI Life Tech, China), and the sequence was compared with the NCBI nucleotide sequence database (https://blast. ncbi.nlm.nih.gov/Blast.cgi?PROGRAM=blastn\&PAGE_T YPE=BlastSearch\&LINK_LOC=blasthome) and deposited under accession number MH806356.1. The phylogenetic tree was constructed using MEGA (version 7) ([33] \#1324). The phylogenetic tree was inferred using the neighbor-joining method. Bootstrap analysis was based on 1000 resamplings.

\section{Pectinase activity assay}

Pectinase activity production was assessed using the 3,5-dinitrosalicylic acid (DNS) method ([29] \#1193; [9] \#1173), and the absorbance was measured at $540 \mathrm{~nm}$ with a UV-VIS spectrophotometer (Cary 50 UV-Vis, Varian, Inc., North America). Cell-free supernatant $(20 \mu \mathrm{l})$ was mixed with $1 \mathrm{~mL}$ pectin $(0.2 \%$, galacturonic acid $\geq 74.0 \%$, Shanghai Macklin Biochemical Co., Ltd.) as the substrate using $\mathrm{NaOH}$-glycine buffer $(50 \mathrm{mmol} / \mathrm{L}$, $\mathrm{pH}$ 9.0) and incubated at $40^{\circ} \mathrm{C}$ for $30 \mathrm{~min}$. DNS solution (1 mL; Beijing Leagene Biotechnology Co., Ltd., China) was added, and the reaction mixture was boiled for 5 min. The absorbance of the cooled reaction mixture was read at $540 \mathrm{~nm}$, while the supernatant was boiled for 5 min to inactivate the pectinase.

A standard curve was established using D-galacturonic acid as the reducing sugar. The final concentrations of the solutions in each tube with $5 \mathrm{~mL}$ DNS solution were $0.008, \quad 0.016,0.024,0.032,0.040$, and $0.048 \mathrm{mg} / \mathrm{mL}$ D-galacturonic acid (Beijing Leagene Biotechnology Co., Ltd.). The tubes were boiled for $5 \mathrm{~min}$ and cooled. A 
blank sample was prepared with distilled water instead of D-galacturonic acid. One unit (U) of polygalacturonase activity was defined as the amount of enzyme that generated $1 \mu \mathrm{mol}$ galacturonic acid per min under the assay conditions. Pectinase activity was calculated using the following formula:

$$
\text { Enzyme Activity }\left(\frac{\mathrm{U}}{\mathrm{ml}}\right)=\frac{1000 \times \Delta \mathrm{A} \times \mathrm{N}}{\mathrm{K} \times \mathrm{M} \times \mathrm{T}}
$$

where $\Delta \mathrm{A}$ is the absorbance of samples subtracted from control absorbance, $\mathrm{N}$ is the dilution factor, $\mathrm{K}$ is the slope of the standard curve, $\mathrm{T}$ is $30 \mathrm{~min}$, and $\mathrm{M}$ is the molecular weight of D-galacturonic acid $(\mathrm{M}=194.14 \mathrm{Da})$.

\section{Optimization of the fermentation conditions}

It is critical to determine the fermentation period of $B$. tequilensis CAS-MEI-2-33 during optimization experiments. We took samples and detected the pectinase activity of the fermentation medium every $4 \mathrm{~h}$ to confirm the maximum activity of pectinase during fermentation. The initial fermentation medium contained $20 \mathrm{~g} / \mathrm{L}$ TS, $0.5 \mathrm{~g} / \mathrm{L} \mathrm{MgSO}_{4}, 3 \mathrm{~g} / \mathrm{L}\left(\mathrm{NH}_{4}\right)_{2} \mathrm{SO}_{4}$, and $0.01 \mathrm{~g} / \mathrm{L} \mathrm{Fe}_{2} \mathrm{SO}_{4}$ at $\mathrm{pH}$ 7.0. Fermentation was performed in shake-flask experiments using $500 \mathrm{~mL}$ shake flasks containing 100 $\mathrm{mL}$ fermentation medium incubated with the strain $B$. tequilensis CAS-MEI-2-33. The culture was grown at $37^{\circ} \mathrm{C}$ and $180 \mathrm{rpm}$. All experiments were performed in triplicate. The reagents were purchased from Sinopharm Chemical Reagent Co., Ltd.

Inocula were prepared using the culture of $B$. tequilensis CAS-MEI-2-33 incubated for $8 \mathrm{~h}$ at $37^{\circ} \mathrm{C}$ in LB. The $\mathrm{OD}_{600}$ of $B$. tequilensis CAS-MEI-2-33 was approximately 4.52 , and the inoculum volume was $1 \%$ of the fermentation volume. All experiments were performed in triplicate. One-way ANOVA with Tukey's test was used to determine any significant differences $(p<0.05)$ between treatments using SAS (Statistical Analysis System, SAS Institute Inc., USA).

To test the toxicity of nicotine to $B$. tequilensis CAS-MEI-2-33, growth of this strain in LB containing nicotine was evaluated in shake-flask experiments using $150 \mathrm{~mL}$ shake flasks containing $50 \mathrm{~mL}$ medium that was incubated with $1 \%(\mathrm{v} / \mathrm{v})$ inocula. Nicotine was added to the LB medium at final concentrations of $0,0.5,1.0$, and $2.0 \mathrm{~g} / \mathrm{L}$. The optical density of the incubation was monitored at $600 \mathrm{~nm}$ every two hours.

Optimization of the $\mathrm{pH}$ was performed in a similar manner for the selected isolate. The initial fermentation medium was prepared with $\mathrm{pH}$ ranging from 6.0-8.0 using $\mathrm{NaOH}$ and the initial medium prior to sterilization at $121^{\circ} \mathrm{C}$ for $20 \mathrm{~min}$. The medium was incubated at $37^{\circ} \mathrm{C}$ and $180 \mathrm{rpm}$ for $40 \mathrm{~h}$.
TS provided the carbon and nitrogen sources in the medium and was important during fermentation. The fermentation medium was prepared with TS concentrations ranging from 10 to $50 \mathrm{~g} / \mathrm{L}$ at the optimal $\mathrm{pH}$. The medium was incubated at $37{ }^{\circ} \mathrm{C}$ and $180 \mathrm{rpm}$ for $40 \mathrm{~h}$.

Effect of the inoculum size on enzyme production was studied with different concentrations of inocula. Different amounts, i.e., $1,3,5,7$, and $9 \%(\mathrm{v} / \mathrm{v})$, were inoculated into the fermentation medium with $40 \mathrm{~g} / \mathrm{L}$ TS at $\mathrm{pH}$ 7.0. The medium was incubated at $37^{\circ} \mathrm{C}$ and $180 \mathrm{rpm}$ for $40 \mathrm{~h}$.

\section{Enzymatic properties}

The enzyme activity was highly influenced by the $\mathrm{pH}$, temperature, and metal ions. The $\mathrm{pH}$ and temperature are important characteristics of a biocatalyst for use in industrial applications. The optimal $\mathrm{pH}$ of pectinase in the cell-free supernatant was assayed using citrate-phosphate (pH 6.0), phosphate ( $\mathrm{pH} 7.0-8.0)$, and glycine- $\mathrm{NaOH}(\mathrm{pH}$ $9.0-11.0$ ) as buffers $(50 \mathrm{mmol} / \mathrm{L}$ ) and $0.2 \%$ pectin (Shanghai Macklin Biochemical Co., Ltd., China) as a substrate at $40^{\circ} \mathrm{C}$. The optimal temperature for pectinase activity was determined by incubating the reaction mixture from $30^{\circ} \mathrm{C}$ to $70^{\circ} \mathrm{C}$ at the optimal $\mathrm{pH}$. The effects of metal ions $\left(\mathrm{Ag}^{+}\right.$, $\mathrm{K}^{+}, \mathrm{Li}^{+}, \mathrm{Cu}^{2+}, \mathrm{Ca}^{2+}, \mathrm{Ba}^{2+}, \mathrm{Co}^{2+}, \mathrm{Ni}^{2+}, \mathrm{Mg}^{2+}, \mathrm{Mn}^{2+}, \mathrm{Zn}^{2+}$, $\mathrm{Cd}^{2+}$, and $\mathrm{Fe}^{3+}$ ) on pectinase activity were assayed at a concentration of $1.0 \mathrm{mM}$ in the reaction mixture. Thermal stability was investigated by measuring pectinase activity every $20 \mathrm{~min}$ following incubation of the enzyme solution at $40{ }^{\circ} \mathrm{C}, 50^{\circ} \mathrm{C}$, and $60^{\circ} \mathrm{C}$.

\section{Purification of pectinase}

According to the optimal fermentation parameter, we obtained approximately $2.30 \mathrm{~L}$ fermentation liquid. After fermentation, the fermentation liquid was centrifuged at $4{ }^{\circ} \mathrm{C}$ and $5000 \times \mathrm{g}$ for $30 \mathrm{~min}$ to collect the supernatant, which contained the alkaline pectinase. Crude protein was obtained after separation with ammonium sulfate fractionation, ion exchange chromatography and column chromatography.

Fifty milliliters of supernatant was placed in an ice bath, and $20,30,40,50,60,70,80$, and $90 \%$ saturation with ammonium sulfate was conducted overnight for protein precipitation. Then, the solution was centrifuged in a high-speed refrigerated centrifuge at $5000 \times \mathrm{g}$ for $15 \mathrm{~min}$ to obtain the precipitate and supernatant. By detecting the pectinase activity of the precipitate and supernatant with different levels of saturation with ammonium sulfate, the ammonium sulfate fractionation curve and suitable saturation were determined. Based on the results from the ammonium sulfate fractionation curve, $70 \%$ saturation with ammonium sulfate was conducted, and the precipitate was removed by centrifugation. Then, the supernatant was brought to $80 \%$ saturation with ammonium sulfate to precipitate 
the target enzyme. The precipitate was crude pectinase. By dialyzing the precipitate a few times in equilibrated buffer, the crude enzyme was obtained.

The crude enzyme was subjected to High-Q ion exchange chromatography (Bio-Rad Laboratories (Shanghai Co., Ltd.)). Then, the column was equilibrated with Tris- $\mathrm{HCl}$ buffer $(\mathrm{pH} 8.0)$ and eluted with a linear salt gradient $(0-1 \mathrm{M} \mathrm{NaCl}$ in $200 \mathrm{~mL}$ Tris- $\mathrm{HCl}$ buffer, 0.4 $\mathrm{mM}, \mathrm{pH}$ 8.0). The eluent was collected automatically at $1 \mathrm{~min} /$ tube.

Sephacryl S-100 was equilibrated with ultrapure water, sampled, and eluted with pH 7.2 PBS buffer, with a flow rate of $0.8 \mathrm{~mL} / \mathrm{min}$, and the effluent was detected by an online UV detector at a wavelength of $280 \mathrm{~nm}$ to record the ultraviolet absorption peak curve. The components were collected, and the enzyme activity and protein content were tested.

\section{Determination of protein content and SDS-polyacrylamide gel electrophoresis (SDS-PAGE)}

The protein content was determined using a BCA (bovine serum albumin) standard curve, and SDSPAGE ([34] \#1297) was conducted to identify the enzyme purity.

\section{LC-MS/MS identification of protein}

Protein bands were cut from the SDS-PAGE gel and subjected to LC-MS/MS (liquid chromatographic-tandem mass spectrometric) analysis by Shanghai Applied Protein Technology ([23] \#1320; [24] \#1321). Protein samples were digested using trypsin for $20 \mathrm{~h}$ at $37^{\circ} \mathrm{C}$. Then, peptides were trapped and desalted on Zorbax 300SB-C18 peptide traps (Agilent Technologies, Wilmington, DE, USA) followed by separation on a C18-reversed-phase column $(0.15 \times 150 \mathrm{~mm}$, Column Technology Inc., Fremont, CA, USA). An Easy nLC system (Thermo Fisher Scientific) was used to deliver mobile phases A $(0.1 \%$ formic acid $)$ and B $(0.1 \%$ formic acid in $84 \%$ acetonitrile) ([35] \#1322) according to routine methods. The mass spectrometer was operated in MS/MS mode scanning from 380 to $1800 \mathrm{amu}$. The top 20 multiply charged ions were selected from each scan for MS/MS analysis ([36] \#1323). Then, the MS/ MS spectra were searched using MASCOT 2.2 (Matrix Science, London, UK), and the protein was identified by searching the $B$. tequilensis database in UniProt (https://www.uniprot.org/).

\section{Additional files}

Additional file 1: Figure S1. The transparent zone around the strain of B. tequilensis CAS-MEI-2-33 on PAPs. (DOCX 65 kb)

Additional file 2: Figure S2. Protein peak detected by IC-MS/MS. The protein was isolated from a gel. (DOCX 78 kb)

\section{Abbreviations}

16S rRNA: 165 ribosomal RNA; ANOVA: Analysis of variance; $B$. tequilensis: Bacillus tequilensis; DNS method: 3,5-dinitrosalicylic acid method; LB: Luria-Bertani; LCMS/MS: Liquid chromatographic-tandem mass spectrometric; PAPs: Pectin agar plates; PCR: Polymerase chain reaction; TS: Tobacco stalk

\section{Acknowledgments}

We thank International Science Editing (http://www.internationalscienceediting. $\mathrm{cn} /$ ) and American Journal Experts (https://www.aje.cn/) for help with English usage.

\section{Funding}

We greatly appreciate the financial support from the Key Program for Science and Technology of Hainan Provincial Branch of the CNTC (2017000024052), the Key Program for Science and Technology of Hainan Provincial Branch of the CNTC (2017000024056), and the Youth Innovation Promotion Association (CAS NO. 2017252). The funders role was providing funding for the study and all other aspects of the project (design, collection, analysis, and interpretation of data and writing of the manuscript) was executed by the authors.

\section{Availability of data and materials}

All data generated or analyzed during this study are included in this published article and its additional files. The datasets generated during the study are available in the NCBI database (https://www.ncbi.nlm.nih. gov/nuccore/MH806356.1/)

\section{Authors' contributions}

GZ carried out the experiments in this study and drafted the manuscript. $H Z$, $\mathrm{MM}$ and $\mathrm{HL}$ conducted the design of the experiment and helped draft and finalize the manuscript. YX and ZS revised the manuscript. SL, JW and YX assisted with the screening and fermentation experiments. FW participated in the pectinase activity detection and data analysis work. All authors read and approved the final manuscript.

Ethics approval and consent to participate

Not applicable.

\section{Consent for publication}

Not applicable.

Competing interests

The authors declare that they have no competing interests.

\section{Publisher's Note}

Springer Nature remains neutral with regard to jurisdictional claims in published maps and institutional affiliations.

\section{Author details}

${ }^{1}$ Key Laboratory of Tobacco Biology and Processing, Tobacco Research Institute of Chinese Academy of Agricultural Sciences, Qingdao 266101, People's Republic of China. ${ }^{2}$ CAS Key Laboratory of Biobased Materials, Qingdao Institute of Bioenergy and Bioprocess Technology, Chinese Academy of Sciences, Qingdao 266101, People's Republic of China. ${ }^{3}$ Haikou Cigar Research Institute, Hainan Provincial Branch of CNTC, Haikou 571100, People's Republic of China. ${ }^{4}$ China Tobacco Standardization Research Center, Zhengzhou Tobacco Research Institute of CNTC, Zhengzhou 450001,

People's Republic of China. ${ }^{5}$ Research and Development Center, China Tobacco Anhui Industrial Co., Ltd., Hefei 230088, People's Republic of China.

Received: 12 April 2018 Accepted: 13 May 2019

Published online: 12 July 2019

References

1. Su Y, Xian H, Shi S, Zhang C, Nuruzzaman MSM, Mao J, Zhang G, Liao W, Wang $\mathrm{Q}$, Liu H. Biodegradation of lignin and nicotine with white rot fungi for the delignification and detoxification of tobacco stalk. BMC Biotechnol. 2016;16(1):81-9.

2. Zhong W, Zhu C, Shu M, Sun K, Zhao L, Wang C, Ye Z, Chen J. Degradation of nicotine in tobacco waste extract by newly isolated Pseudomonas $s p$. ZUTSKD. Bioresour Technol. 2010;101(18):6935-41. 
3. Hu R, Wang J, Li H, Ni H, Chen Y, Zhang Y, Xiang S, Li H. Simultaneous extraction of nicotine and solanesol from waste tobacco materials by the column chromatographic extraction method and their separation and purification. Sep Purif Technol. 2015;146:1-7.

4. Yuan Y, Lu Z, Huang L, Li Y, Lu F, Bie X, Teng Y, Lin Q. Biodegradation of nicotine from tobacco waste extract by Ochrobactrum intermedium DN2. J Ind Microbiol Biotechnol. 2007;34(8):567-70.

5. Tuzzin G, Godinho M, Dettmer A, Zattera AJ. Nanofibrillated cellulose from tobacco industry wastes. Carbohyd Polym. 2016;148:69-77.

6. Kohli P, Gupta R. Alkaline pectinases: a review. Biocatal Agr Biotechnol. 2015;4(3):279-85

7. Ahlawat S, Mandhan RP, Dhiman SS, Kumar R, Sharma J. Potential application of alkaline pectinase from Bacillus subtilis SS in pulp and paper industry. Appl Biochem Biotechnol. 2008;149(3):287-93.

8. Ahlawat S, Dhiman SS, Battan B, Mandhan RP, Sharma J. Pectinase production by Bacillus subtilis and its potential application in biopreparation of cotton and micropoly fabric. Process Biochem. 2009:44(5):521-6.

9. Jayani RS, Saxena S, Gupta R. Microbial pectinolytic enzymes: a review. Process Biochem. 2005;40(9):2931-44.

10. Akbar $S$, Prasuna RG. Exploitation of fruit wastes for pectinase production using Aspergillus oryzae. Int J Pharm Bio Sci. 2012;3(3):756-65.

11. Kumar A, Sharma R. Production of alkaline pectinase by bacteria (Cocci sps.) isolated from decomposing fruit materials. J Phytopathol. 2012;4(1):01-5.

12. Patil RC, Murugkar TP, Shaikh SA. Extraction of pectinase from pectinolytic bacteria isolated from carrot waste. Int J Pharma Bio Sci. 2012;3(1):B261-6.

13. Pereira GS, Cipriani M, Wisbeck E, Souza O, Strapazzon JO, Gern RMM. Onion juice waste for production of Pleurotus sajor-caju and pectinases. Food Bioprod Process. 2017;106:11-8.

14. Hoondal GS, Tiwari RP, Tewari R, Dahiya N, Beg QK. Microbial alkaline pectinases and their industrial applications: a review. Appl Microbiol Biotechnol. 2002;59(4-5):409-18.

15. Xiao $R$, Chen $Y$. Research progress on comprehensive utilization of tobacco stalk. Sci Technol Inform. 2012;15:55

16. Gummadi SN, Panda T. Purification and biochemical properties of microbial pectinases a review. Process Biochem. 2003;38(2003):987-96.

17. El-Enshasy HA, Elsayed AE, Suhaimi N, Malek RA, Esawy M. Bioprocess optimization for pectinase production using Aspergillus niger in a submerged cultivation system. BMC Biotechnol. 2018;18(2018):71.

18. R. EB, N. EG. Bergey's manual of determinative bacteriology eight edition(in Chinese). Beijing: Science Press; 1984.

19. Reddy MP, Saritha KV. Effects of the culture media optimization on pectinase production by Enterobacter sp. PSTB-1. Biotech. 2016;6(2):207-17.

20. Uzuner S, Cekmecelioglu D. Enhanced pectinase production by optimizing fermentation conditions of Bacillus subtilis growing on hazelnut shell hydrolyzate. J Mol Catal B-Enzym. 2015;113:62-7.

21. Kaur P, Satyanarayana T. Production and starch saccharification by a thermostable and neutral glucoamylase of a thermophilic mould Thermomucor indicae-seudaticae. World J Microb Biot. 2004;20(4):419-25.

22. Amid M, Manap Y, Zohdi K. Purification and characterisation of thermoalkaline pectinase enzyme from Hylocereus polyrhizus. Eur Food Res Technol. 2014;239(1):21-9.

23. Gao L, Li Z, Xia C, Qu Y, Liu M, Yang P, Yu L, Song X. Combining manipulation of transcription factors and overexpression of the target genes to enhance lignocellulolytic enzyme production in Penicillium oxalicum. Biotechnol Biofuels. 2017:10(1):100-17.

24. Qian W, Gang X, Zhang T, Wei L, Yang X, Li Z, Yang Y, Song L, Wang P, Peng J, et al. Protein kinase a-mediated phosphorylation of the broadcomplex transcription factor in silkworm suppresses its transcriptional activity. J Biol Chem. 2017;292(30):12460-70.

25. El-Sayed MH. Thermoalkali-stable pectinase from Bacillus subtilis strain NVFO 19 isolated from agricultural waste dump soil. Curr Res Microbiol Biotechn. 2015:3(6):805-15.

26. Tosin AB, Maria BO, Omowunmi OO, Oladipo AO. Pectinase production by Bacillus megaterium, Bacillus bataviensis and Paenibacillus sp. isolated from decomposing wood residues in the Lagos lagoon. J Trop Life Sci. 2017;7(3):204-7

27. Chowdhury TI, Jubayer F, Uddin B, Aziz G. Production and characterization of pectinase enzyme from rhizopus oryzae. Slovak J Food Sci. 2017;11(1):641-51.

28. Chiliveri SR, Koti S, Linga VR. Retting and degumming of natural fibers by pectinolytic enzymes produced from Bacillus tequilensis SV11-UV37 using solid state fermentation. Springerplus. 2016;5(1):559-75.
29. Meneghel L, Reis G, Reginatto C, Malvessi E. Silveira MMd. Assessment of pectinase production by Aspergillus oryzae in growth-limiting liquid medium under limited and non-limited oxygen supply. Process Biochem. 2014; 49(11):1800-7.

30. Fawole OB, Odunfa SA. Some factors affecting production of pectic enzymes by Aspergillus niger. Int Biodeterior Biodegradation. 2003;52(4):223-7.

31. Guo P, Xia Y, Li R, Lü Y, Qiu M, Zhao W, Yu Y. Assessment of tobacco specific nitrosamines in tobacco genotypes. Adv Mater Res. 2013;641-642(1):871-4.

32. Yu P, Xu C. Production optimization, purification and characterization of a heat-tolerant acidic pectinase from Bacillus sp. ZJ1407. Int J Biol Macromol. 2017:108:972-80.

33. Kumar S, Stecher G, Tamura K. MEGA7: molecular evolutionary genetics analysis version 7.0 for bigger datasets. Mol Biol Evol. 2016:33(7):1870-4.

34. Celestino SMC, Maria dFS, Javier MF, MVd S, Filho EXF. Purification and characterization of a novel pectinase from Acrophialophora nainiana with emphasis on its physicochemical properties. J Biotechnol. 2006;123(1):33-42.

35. Martin P, Julie K, Ri-T A, Vasiliki B, George M, Antonia V, William M, Harald M, Vera J. Comparison of higher energy collisional dissociation and collisioninduced dissociationMS/MS sequencing methods for identification of naturally occurring peptides in human urine. Proteomics Clin Appl. 2015;9:531-42.

36. Huang J, Liu T, Li K, Song X, Yan R, Xu L, Li X. Proteomic analysis of protein interactions between Eimeria maxima sporozoites and chicken jejunal epithelial cells by shotgun LC-MS/MS. Parasite Vector. 2018;11(1):226-35.
Ready to submit your research? Choose BMC and benefit from:

- fast, convenient online submission

- thorough peer review by experienced researchers in your field

- rapid publication on acceptance

- support for research data, including large and complex data types

- gold Open Access which fosters wider collaboration and increased citations

- maximum visibility for your research: over $100 \mathrm{M}$ website views per year

At BMC, research is always in progress.

Learn more biomedcentral.com/submissions 